${ }^{1}$ Departement of Social and Preventive Medicine, Social and Behavioural Health Research, University of Berne, Switzerland

${ }^{2}$ Robert-Koch Institute, Child and Adolescent Health, Berlin, Germany

\title{
Health-related quality of life: gender differences in childhood and adolescence
}

\author{
Submitted: 28 September 2004 \\ Accepted: 15 June 2005 \\ Published Online First: 21 September 2005
}

\section{Summary}

Objectives: To assess whether gender and age differences can be found in different aspects of health-related quality of life (HRQOL) of children and adolescents, and to what extent these results correspond to theoretical and empirical findings from developmental psychology.

Methods: A newly developed HRQOL questionnaire was completed by 3710 youths aged nine to 17 years in seven European countries. The "Kidscreen 52" questionnaire consists of 10 scales operationalising aspects of the physical, psychological and social dimensions of HRQOL. With the use of ANOVA and effect sizes, the influence of age and gender on aspects of HRQOL is reported.

Results: Children report a very good quality of life largely independent of gender. After 12 years, HRQOL decreases in the majority of aspects. In the physical and psychological dimensions, a stronger decrease is found for females than for males.

Conclusions: Children have higher HRQOL than adolescents in many aspects. With increasing age, HRQOL is frequently worse for females than for males. Examination of the individual aspects leads to a differentiation of the results with relevance for public health.

Keywords: Health-related quality of life - Childhood development - Adolescent development - Gender differences - Age differences.

Health-related quality of life (HRQOL) as a general health outcome is of growing interest in public health (Nutbeam 2000). The use of such a health-oriented outcome is especially suitable for the evaluation of children and adolescents, considering the low mortality and morbidity in these groups (European Commission 2000). In a primarily healthy population,
HRQOL can discriminate among different levels of physical, psychological and social well-being. Furthermore, knowing more about the HRQOL of children and adolescents is of special relevance in public health because quality of life in this age is the basis for quality of life and health in adulthood.

As individuals, children and adolescents learn to interact with society, developing physically, psychologically and socially. Between birth and young adulthood they broaden their horizons within developing systems of life domains (Bronfenbrenner 1981). At the same time, the social environment poses age-specific challenges, so called developmental tasks (Havighurst 1966), e. g. starting school, separating from parents or dealing with the changing body in puberty.

As the child ages, developmental tasks become increasingly gender specific, and are linked to different burdens and resources. Thus, developmental tasks may cause not only age-related differences in HRQOL, but, especially for adolescents, also gender-related differences. As a result, evaluation of the health and quality of life of children and adolescents in various age groups must include separation by gender as well (Kolip \& Schmidt 1999).

The European Commission's 2000 report on the health of adolescents specifies a "shift in gender-related health status between childhood and adolescence". According to the report, boys have more health problems than girls in childhood, whereas in adolescence young women demonstrate psychosomatic disorders and emotional disturbances more frequently than young men.

Age and gender differences in HRQOL are not completely clarified in the literature, however. In some individual aspects, as well as in a general index of HRQOL, values seen in children are often higher than those seen in adolescents (RavensSieberer et al. 2000; Simeoni et al. 2000). With regard to gender differences the findings are unclear, but several studies tend to indicate higher values in adolescent males than in 
adolescent females (Ravens-Sieberer et al. 2000; 2003; Bullinger et al. 2001; Simeoni et al. 2000). Gender differences in the HRQOL of children are even less clear, or are not found at all (Ravens-Sieberer et al. 2000).

The diverse results regarding differences in gender and age stem partly from the fact that they are based on different questionnaires with in some cases very different concepts and operationalisations of HRQOL. This highlights the importance of addressing the various aspects as comprehensively as possible for the life domains of the target group when investigating HRQOL, and of incorporating a broadly accepted definition of HRQOL in the sense of subjective health encompassing well-being and functioning in physical, psychological, mental, social and everyday domains as perceived and expressed by the respondent (Bullinger et al. 2000).

Based on this concept, the project "Kidscreen", financed by the European Commission, developed a questionnaire that measures HRQOL of children and adolescents on ten scales (Ravens-Sieberer et al. 2001; European Kidscreen group 2005). With this questionnaire it is possible to investigate specific aspects of the quality of life of children and adolescents, such as psychological well-being, relationship to parents, or self perception.

The Kidscreen questionnaire comprises identical questions for children and adolescents. Thus, with the European cross sectional study presented here, various aspects of the HRQOL of 9- to 17-year-old male and female children and adolescents can be compared directly for different age groups and for both genders.

\section{Methods}

\section{Sample}

The Kidscreen pilot study included 3977 children and adolescents from the seven European countries Austria, France, Germany, The Netherlands, Spain, Switzerland and the United Kingdom. In The Netherlands a representative sample was drawn. In the other countries the pilot study was carried out in schools from different regions (urban vs. rural) and different socio-economic environments in order to gain heterogeneous samples.

Children and adolescents completed a self-administered paper and pencil questionnaire (European Kidscreen group 2005).

\section{Questionnaire}

"Kidscreen 52" is a new research instrument making it possible to operationalise HRQOL in the following 10 scales: "Physical well-being", "Psychological well-being", "Moods and emotions", "Self perception", "Autonomy", "Parent re- lations and home life", "Peers and social support", "School environment", "Social acceptance (bullying)" and "Financial resources". In Table 3 all scales are characterised more in details. It is the first questionnaire in the field of HRQOL of children and adolescents which has been developed from the onset in multiple languages and for the large age span from eight to 18 years. The contents of the questionnaire were compiled from an expert view with a literature research and a delphi study (Rajmil et al. 2004; Herdman et al. 2002) as well as with input from children's and adolescents' focus groups (Detmar et al. 2005). For the translation a forward-backwardtechnique with reconciliation was used and the questionnaires were pre-tested by cognitive interviews in order to guarantee a good cross-cultural validity. The pilot study reported here was conducted in order to reduce the number of items and to build up the scales of the instrument using factor analyses and IRT (item response theory) analyses. The 10 scales, each including three to seven items, are summed up and transformed linearly to values from 0 to 100 (higher values show better HRQOL). The following items with five answer categories indicating frequency or intensity provide a representative illustration of the content of the questionnaire: "Have you felt full of energy?" (physical); "Have you had enough time for yourself?" (autonomy); "Have your parent(s) treated you fairly?" (parents). The scales show convincing coefficients (Cronbach's alpha $=0.76$ to 0.88 ) and fulfil the assumptions of the Rasch model in all countries, for both genders and for children as well as for adolescents. More detailed information about the questionnaire, including development and further validation, are available on the world wide web (www.kidscreen.org).

\section{Analysis}

On a theoretical as well as an empirical basis, age and gender differences in the HRQOL of children and adolescents are to be expected. These differences vary for diverse aspects of HRQOL. In the present article we address the following questions:

- In which aspects of the HRQOL of male and female children and adolescents can gender differences be seen, and for which gender is the quality of life higher?

- In which aspects of the HRQOL of children and adolescents can age differences be seen, and for which age group is the quality of life higher?

- Which age differences in HRQOL of children and adolescents can be seen if females and males are examined separately?

To check the questions empirically we formulated genderand age-specific hypotheses for each scale based on existing studies. The studies come either from quality-of-life 
research in children and adolescents or from developmental psychology constructs which are relevant to the 10 scales of the Kidscreen instrument and their definitions in terms of content.

ANOVA were used with each of the Kidscreen scales as dependent variable and "gender" (two levels) and "age" (nine levels, age groups from nine to 17 years) as independent factors. With such large sample sizes, inferential tests show significances even for very small differences. For this reason, effect sizes were taken into account to describe meaningful differences: For every scale, relevant Eta squares $\left(\eta^{2}\right)$ are reported as descriptive measures for age and gender differences and for their interaction. Eta square indicates the proportion of the variance of the dependent variable explained by the independent variables. Critical values for Eta square are: $\eta^{2} \geq$ 0.01: small effect; $\eta^{2} \geq 0.06$ : medium effect; $\eta^{2} \geq 0.14$ : large effect (deduced from $\mathrm{f}$ thresholds of 0.1 / 0.25 / 0.4 according to Bortz \& Döring 1995). In order to gain more information about continuous age differences beyond linear correlations, trend analyses were computed.

To go into greater detail, differences between adjacent age groups were computed for each scale and for girls and boys separately. Contrasts (i. e. planned comparisons) were computed to test significance, and considered as relevant with effect sizes $d$ (i. e. mean difference divided by shared standard deviation) exceeding critical values as follows: $d \geq 0.2$ : small effect; $d \geq 0.5$ : medium effect; $d \geq 0.8$ : large effect (Bortz \& Döring 1995). Finally, for each scale, gender differences are computed within each age group, considering contrast tests and effect sizes d, with the critical values mentioned above.

In all cases, differences are reported as meaningful if the inferential test is significant and there is at least a small effect, based on the definitions above. For the scales of the Kidscreen instrument, means per age group and gender are presented in figures if they are showing meaningful effects.

\section{Results}

\section{Sample}

Even though the national samples were mostly collected in schools the response rates are in some cases not very high since in most countries the parents had to agree to participate by written consent beforehand (Tab. 1).

For this study the sample was reduced to exclude cases with missing information about age $(n=54)$ or gender $(n=24)$. Due to small groups, children younger than nine years $(\mathrm{n}=$ $105)$ and adolescents older than 17 years $(n=98)$ were excluded, resulting in a sample with 3710 children and adolescents between the ages of nine and 17 years (Tab. 2).

\section{Testing the hypotheses}

The tested hypotheses and the concerning results are presented in Tab. 3, along with the 10 Kidscreen scales and their definitions.

E. g. for the scale "physical well-being" in Tab. 3 it can be seen that, based on our knowledge, we presumed higher quality-of-life values for adolescent males than for females. Furthermore, drawing on information from the sources mentioned we assumed lower values for all adolescents compared with all children in this scale. In the following results both assumptions are shown to be accepted.

In the overview of the 14 formulated hypotheses the following pattern can be seen (Tab. 3): Consistent with the general presumptions of the quality-of-life research for the physical and psychological aspects of HRQOL (scales "physical", "psychological", "mood" and "self") we expected higher values for children compared to adolescents and higher values for adolescent males compared to adolescent females (however the scale "self" we could not hypothesise age differences). For the scales "parents" and "school" - i. e. for the social scales that involve adults - we also supposed higher values for children compared to adolescents. Based on previous published research, however, we did not expect gender differences in adolescents for the scale "school". In contrast to the other scales, for the peer-related scales "peers" and "acceptance" we assumed higher values for adolescents compared to children as well as higher values for female (children and) adolescents than for males. Concerning the HRQOL aspects "autonomy" and "financial" we were not aware of any research on which to base hypotheses.

With one exception we couldn't formulate any gender-specific hypotheses for children due to a lack of supporting empirical results. From the perspective of developmental psychology we can presume that gender-specific differences first become apparent with the onset of adolescence.

\section{Illustration of the results}

For a better overview and to facilitate the interpretation of the data in Figures 1a to 1g, the means of the seven Kidscreen scales showing meaningful effects are reproduced across the age groups, separated for both genders. The values between 0 and 50 have been omitted because all means were between 50 and 100 .

\section{ANOVA main effects and interactions}

In the ANOVA with the three scales "physical", "mood" and "self" as dependent variables, the factors gender and age and their interaction are all meaningful according to the formulated criteria ( $p<0.5$ as well as $\left.\eta^{2} \geq 0.01\right)$. The exact values are reported in Fig. 1. For each of the four scales "psychological", "parents", "school" and "acceptance", only the factor age has 
Table 1 Sample of the Kidscreen Pilot Study: children and adolescents from 8 to 18 years $(n=3977)$

\begin{tabular}{|c|c|c|c|c|c|c|c|c|}
\hline Pilot study sample & Austria & France & Germany & $\begin{array}{l}\text { Nether- } \\
\text { lands }\end{array}$ & Spain & $\begin{array}{l}\text { Switzer- } \\
\text { land }\end{array}$ & $\begin{array}{l}\text { United } \\
\text { Kingdom }\end{array}$ & Total \\
\hline $\begin{array}{l}\text { \# of surveyed children/ } \\
\text { adolescents }\end{array}$ & 412 & 450 & 1326 & 362 & 491 & 491 & 445 & 3977 \\
\hline Response rate & $76.0 \%$ & $60.1 \%$ & $48.1 \%$ & $57.9 \%$ & $87.1 \%$ & $89.3 \%$ & n.i. & $56.7 \%$ \\
\hline $\begin{array}{l}\text { Female, percentage of the } \\
\text { national sample }\end{array}$ & $44.9 \%$ & $55.3 \%$ & $49.2 \%$ & $49.4 \%$ & $49.7 \%$ & $56.4 \%$ & $49.2 \%$ & $50.7 \%$ \\
\hline Mean age (SD) & $12.8(2.8)$ & $13.2(1.3)$ & $12.6(2.4)$ & $12.2(3.6)$ & $12.8(2.8)$ & $13.3(2.8)$ & $11.9(2.4)$ & $12.7(2.6)$ \\
\hline
\end{tabular}

n.i.: no information

Table 2 Sample included in the analyses: children and adolescents from 9 to 17 years $(n=3710)$

\begin{tabular}{|c|c|c|c|c|c|c|c|c|c|c|}
\hline \multicolumn{11}{|c|}{ Age } \\
\hline & 9 & 10 & 11 & 12 & 13 & 14 & 15 & 16 & 17 & Total \\
\hline Female & 235 & 232 & 175 & 212 & 224 & 269 & 236 & 198 & 98 & 1879 \\
\hline Male & 224 & 198 & 231 & 242 & 230 & 249 & 206 & 176 & 75 & 1831 \\
\hline Total & 459 & 430 & 406 & 454 & 454 & 518 & 442 & 374 & 173 & 3710 \\
\hline
\end{tabular}

a noticeable effect, although the factor gender nearly reaches relevance for the scale "psychological" (Fig. 1). When differences in age are considerable, trend analyses beyond linear effects show significant linear terms $(\mathrm{p}<0.001)$, either with continuous decrease, with correlations between $r=-0.10$ (scale "mood") and $r=-0.35$ ("school"), or with continuous increase, with $r=0.21$ ("acceptance"). For the three scales "autonomy", "peers" and "financial" no meaningful differences could be found.

\section{Means and standard deviations for different groups}

Means and standard deviations of all groups of the same age as well as of the same gender are calculated in order to identify meaningful mean differences between two groups, i. e. significant contrasts as well as small or medium effect sizes. Most of the relevant age differences between adjacent age groups are located between 12 and 13 years. Meaningful gender differences are mainly found for adolescents from 12 years upward, mostly with higher values for male adolescents compared to females (see Fig. 1).

Meaningful gender and age differences in the above defined sense (significant and of relevant effect size) are reported below in four thematic groups of aspects. Tab. 3 shows the examination of the formulated hypotheses.

\section{Physical and psychological aspects of HRQOL}

In the majority of cases for both genders, values decrease with increasing age for the physical and psychological aspects of
HRQOL (Figs. 1a, 1b, 1c, and 1d). When the genders are examined separately, no meaningful decrease can be found for male children and adolescents for the scale "mood", whereas for the scales "physical" and "self" the values decrease more with increasing age for female children and adolescents than for males ("physical": female $9 \mathrm{y}: \mathrm{m}=77.2$ / $\mathrm{sd}=16.9$; female 17 y: $\mathrm{m}=56.2$ / sd = 18.2; "self": female 9 y: $\mathrm{m}=82.6$ / $\mathrm{sd}=16.9$; female $17 \mathrm{y}: \mathrm{m}=59.0 / \mathrm{sd}=22.0$ ). These results correspond to the meaningful gender differences and interactions for the scales "physical", "mood" and "self", whereas this pattern was not approved statistically for the scale "psychological". Four out of five meaningful age differences in this domain of HRQOL are found for female adolescents between 12 and 13 years of age.

In the scale "self", gender differences can already be found in childhood, with lower values for girls (female $10 \mathrm{y}: \mathrm{m}=81.0$ / $\mathrm{sd}=17.2$; male $10 \mathrm{y}: \mathrm{m}=87.7 / \mathrm{sd}=15.7$ ), and these differences increase with increasing age (female $17 \mathrm{y}: \mathrm{m}=59.0$ / $\mathrm{sd}=22.0$; male $17 \mathrm{y}: \mathrm{m}=78.5$ / sd = 19.5). For the scales "physical", "psychological" and "mood" young women report considerably lower values than young men, beginning with the ages of 12 or 13 years (e.g. "mood": female $13 \mathrm{y}: \mathrm{m}$ $=73.3$ / sd $=18.7$; male $13 \mathrm{y}: \mathrm{m}=80.8 / \mathrm{sd}=18.0$ ).

Thus six of the seven hypotheses formulated in this domain could be confirmed (Tab. 3), whereas the effect size of the seventh hypothesis was too small. In addition, a meaningful age difference is shown for the scale "self". Therefore, the previous findings concerning physical and psychological 
Health-related quality of life:

gender differences in childhood and adolescence

Table 3 Overview of the established hypotheses and the concerning results

\begin{tabular}{|c|c|c|c|c|c|}
\hline Kidscreen scales and definitions & $\begin{array}{l}\text { Hypotheses } \\
\text { concerning } \\
\text { gender }\end{array}$ & $\begin{array}{l}\text { Results con- } \\
\text { cerning gender }\end{array}$ & $\begin{array}{l}\text { Hypotheses } \\
\text { concerning age }\end{array}$ & $\begin{array}{l}\text { Results con- } \\
\text { cerning age }\end{array}$ & Sources \\
\hline $\begin{array}{l}\text { Physical well-being ("physical") reflects } \\
\text { the level of the child's/adolescent's physi- } \\
\text { cal activity, energy and fitness. The extent } \\
\text { to which he/she feels unwell and com- } \\
\text { plains of poor health is examined. }\end{array}$ & $\begin{array}{l}\text { Higher values } \\
\text { for male ado- } \\
\text { lescents }\end{array}$ & $\checkmark$ & $\begin{array}{l}\text { Higher values } \\
\text { for children }\end{array}$ & $\checkmark$ & $\begin{array}{l}\text { Chipuer et al. 2003; } \\
\text { Haugland et al. 2001; } \\
\text { Narring et al. 2004; } \\
\text { Ravens-Sieberer et al. } \\
\text { 2003; Wade \& Vingilis } \\
1999\end{array}$ \\
\hline $\begin{array}{l}\text { Psychological well-being ("psychological") } \\
\text { reveals positive feelings and emotions } \\
\text { such as happiness, joy, and cheerfulness. }\end{array}$ & $\begin{array}{l}\text { Higher values } \\
\text { for male ado- } \\
\text { lescents }\end{array}$ & $\begin{array}{l}\text { Differences not } \\
\text { meaningful }\end{array}$ & $\begin{array}{l}\text { Higher values } \\
\text { for children }\end{array}$ & $\checkmark$ & $\begin{array}{l}\text { Chipuer et al. 2003; } \\
\text { Narring et al. 2004; } \\
\text { Ravens-Sieberer et al. } \\
\text { 2003; Simeoni et al. } \\
\text { 2000; Wolman et al. } \\
1994\end{array}$ \\
\hline $\begin{array}{l}\text { Moods and emotions ("mood") covers } \\
\text { how often the child/adolescent experi- } \\
\text { ences depressive moods and emotions and } \\
\text { stressful feelings. High values represent a } \\
\text { low level of negative feelings. }\end{array}$ & $\begin{array}{l}\text { Higher values } \\
\text { for male ado- } \\
\text { lescents }\end{array}$ & $\checkmark$ & $\begin{array}{l}\text { Higher values } \\
\text { for children }\end{array}$ & $\checkmark$ & $\begin{array}{l}\text { Bergman \& Scott 2001; } \\
\text { Flammer \& Alsaker } \\
\text { 2002; Narring et al. } \\
\text { 2004; Ravens-Sieberer } \\
\text { et al. 2003; Topolski et } \\
\text { al. } 2001\end{array}$ \\
\hline $\begin{array}{l}\text { Self perception ("self") explores the } \\
\text { extent to which the appearance of the } \\
\text { individual's body is viewed positively, and } \\
\text { includes questions concerning satisfaction } \\
\text { with looks as well as with clothes and } \\
\text { other personal accessories. }\end{array}$ & $\begin{array}{l}\text { Higher values } \\
\text { for male ado- } \\
\text { lescents }\end{array}$ & $\checkmark$ & No hypothesis & $\begin{array}{l}\text { Higher values } \\
\text { for children }\end{array}$ & $\begin{array}{l}\text { Bergman \& Scott 2001; } \\
\text { Flammer \& Alsaker } \\
\text { 2002; Narring et al. } \\
\text { 2004; Roeser et al. 2001; } \\
\text { Topolski et al. } 2001\end{array}$ \\
\hline $\begin{array}{l}\text { Autonomy ("autonomy") examines the } \\
\text { child's/adolescent's level of autonomy, } \\
\text { looking at the opportunity given to a } \\
\text { child or adolescent to define his/her social } \\
\text { and leisure time. }\end{array}$ & No hypothesis & No differences & No hypothesis & No differences & $\begin{array}{l}\text { Chawla 2002; Simeoni } \\
\text { et al. 2000; Flammer \& } \\
\text { Alsaker 2002; Moffitt } \\
\text { 1993; Dreher \& Dreher } \\
1985\end{array}$ \\
\hline $\begin{array}{l}\text { Parent relations and home life ("parents") } \\
\text { explores the quality of the interaction } \\
\text { between the child/adolescent and the } \\
\text { parent or carer, including feelings of } \\
\text { being loved, understood and supported } \\
\text { by the parents. }\end{array}$ & No hypothesis & No differences & $\begin{array}{l}\text { Higher values } \\
\text { for children }\end{array}$ & $\checkmark$ & $\begin{array}{l}\text { Bergman \& Scott 2001; } \\
\text { Fend 2001; Klocke \& } \\
\text { Becker 2003; Ravens- } \\
\text { Sieberer et al. 2003; } \\
\text { Simeoni et al. 2000; } \\
\text { Topolski et al. } 2001\end{array}$ \\
\hline $\begin{array}{l}\text { Peers and social support ("peers") exam- } \\
\text { ines social relations with friends and peers } \\
\text { and whether the child/adolescent feels } \\
\text { accepted and supported by them. }\end{array}$ & $\begin{array}{l}\text { Higher values } \\
\text { for female ado- } \\
\text { lescents }\end{array}$ & No differences & $\begin{array}{l}\text { Higher values } \\
\text { for adolescents }\end{array}$ & No differences & $\begin{array}{l}\text { Colarossi \& Eccles 2000; } \\
\text { Klocke \& Becker 2003; } \\
\text { Phillipsen 1999; Ravens- } \\
\text { Sieberer et al. 2003; } \\
\text { Simeoni et al. } 2000\end{array}$ \\
\hline $\begin{array}{l}\text { School environment ("school") explores } \\
\text { the child's/adolescent's perception of } \\
\text { his/her cognitive capacity for learning and } \\
\text { concentration and his/her feelings about } \\
\text { school, including the relationship with } \\
\text { his/her teachers. }\end{array}$ & $\begin{array}{l}\text { No differences } \\
\text { between fe- } \\
\text { male and male } \\
\text { adolescents }\end{array}$ & $\checkmark$ & $\begin{array}{l}\text { Higher values } \\
\text { for children }\end{array}$ & $\checkmark$ & $\begin{array}{l}\text { Bilz et al. 2003; Ravens- } \\
\text { Sieberer et al. 2003; } \\
\text { Simeoni et al. } 2000\end{array}$ \\
\hline $\begin{array}{l}\text { Social acceptance (bullying) ("accept- } \\
\text { ance") investigates the feeling of being } \\
\text { rejected by others as well as anxiety } \\
\text { caused by peers. Scores are presented in a } \\
\text { positive direction. }\end{array}$ & $\begin{array}{l}\text { Higher values } \\
\text { for female } \\
\text { children and } \\
\text { adolescents }\end{array}$ & No differences & $\begin{array}{l}\text { Higher values } \\
\text { for adolescents }\end{array}$ & $\checkmark$ & $\begin{array}{l}\text { Alsaker 2003; Bilz et al. } \\
\text { 2003; Craig 1998; Rigby } \\
\text { 2002; Schäfer } 1996\end{array}$ \\
\hline $\begin{array}{l}\text { Financial resources ("financial") reflects } \\
\text { whether the child/adolescent feels that } \\
\text { he/she has enough financial resources to } \\
\text { allow him/her to live a lifestyle which is } \\
\text { comparable to other children/adolescents } \\
\text { and therefore has the opportunity to do } \\
\text { things with peers. }\end{array}$ & No hypothesis & No differences & No hypothesis & No differences & $\begin{array}{l}\text { Chipuer et al. 2003; } \\
\text { Fend 1998; cited from } \\
\text { Flammer \& Alsaker } 2002\end{array}$ \\
\hline
\end{tabular}




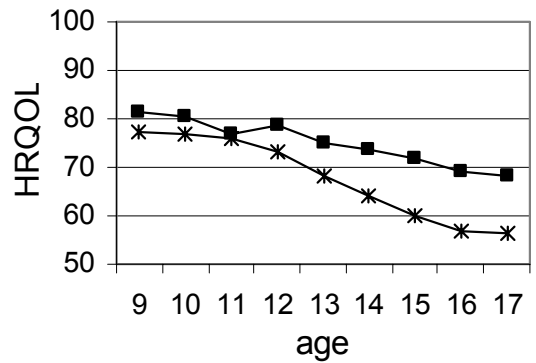

Figure 1a Physical Well-Being ( $\mathrm{N}=3688$ )

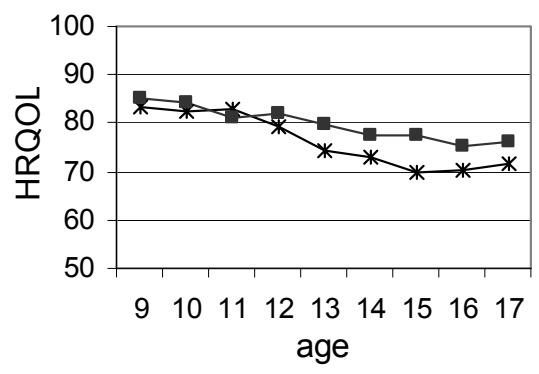

Figure 1b Psychological Well-Being $(\mathrm{N}=3663)$

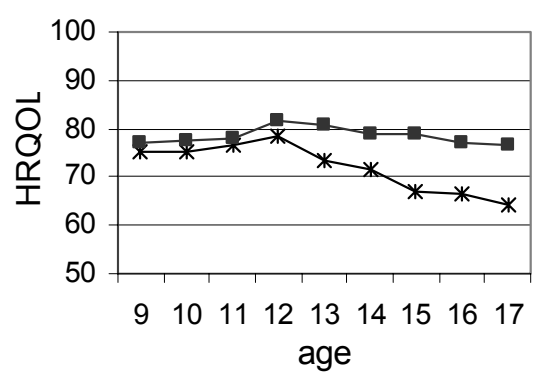

Figure 1c Moods and Emotions ( $N=3653)$

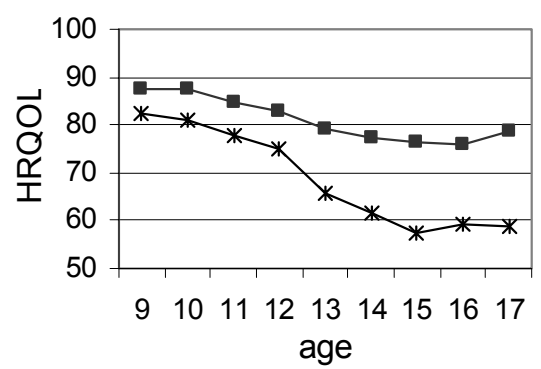

Figure 1d Self Perception ( $N=3673$ ) gender:

$\eta^{2}=0.04 * * *$

age:

$\eta^{2}=0.10 * * *$

interaction:

$\eta^{2}=0.01 * * *$

gender:

$\eta^{2}=0.009 * * *$

age:

$$
\eta^{2}=0.05^{* * *}
$$

gender:

$\eta^{2}=0.03 * * *$

age:

$\eta^{2}=0.02 * * *$

interaction:

$\eta^{2}=0.01 * * *$

gender:

$\eta^{2}=0.09 * * *$

age:

$\eta^{2}=0.12^{* * *}$

interaction:

$\eta^{2}=0.02 * * *$

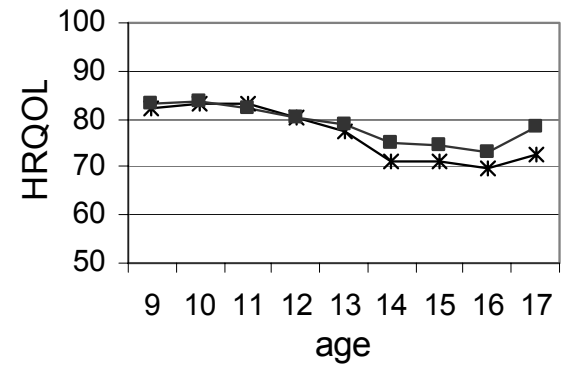

age:

$\eta^{2}=0.05 * * *$

Figure 1e Parent Relations and Home Life $(\mathrm{N}=3618)$

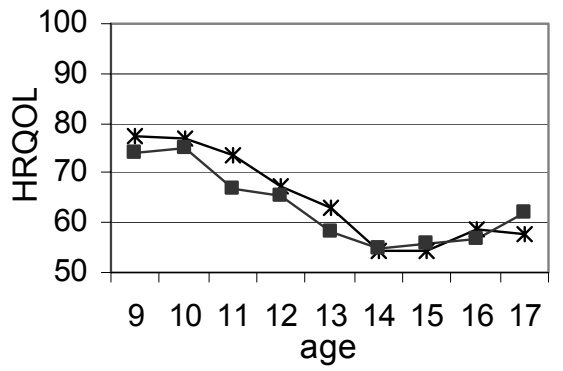

age:

$\eta^{2}=0.15^{* * *}$

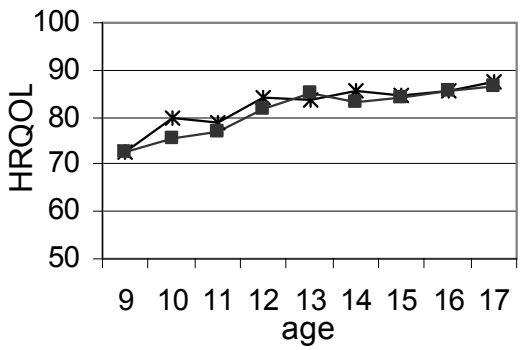

age:

$\eta^{2}=0.05 * * *$

Figure 1g Social Acceptance (Bullying) $(\mathrm{N}=3572)$

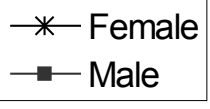

$\eta^{2} \geq 0.01:$ small effect

$\eta^{2} \geq 0.06$ : medium effect

$\eta^{2} \geq 0.14$ : large effect

$* * *: \mathrm{p}<0.001$ 
aspects of HRQOL are confirmed and extended: not only do children have greater physical and psychological well-being than adolescents, and not only are physical and psychological well-being greater for male adolescents than for females, but with increasing age, the well-being of girls decreases to a much greater extent than the well-being of boys.

\section{Social aspects of HRQOL concerning parents and school}

The values of the scales "parents" and "school" decrease with increasing age of the respondents, whereas they rise slightly for the oldest adolescents (Fig. 1e and 1f; "parents": female $9 \mathrm{y}: \mathrm{m}=82.1 / \mathrm{sd}=16.9$; female $17 \mathrm{y}: \mathrm{m}=72.8 / \mathrm{sd}=22.4$; male $9 \mathrm{y}: \mathrm{m}=83.3 / \mathrm{sd}=16.5$; male $17 \mathrm{y}: \mathrm{m}=78.6 / \mathrm{sd}=$ 18.6; "school": female $9 \mathrm{y}: \mathrm{m}=77.5 / \mathrm{sd}=17.7$; female 17 $\mathrm{y}: \mathrm{m}=57.6 / \mathrm{sd}=18.3$; male $9 \mathrm{y}: \mathrm{m}=74.2 / \mathrm{sd}=20.6$; male $17 \mathrm{y}: \mathrm{m}=62.0 / \mathrm{sd}=19.2$ ). The significance and effect size of the age-related differences are clear, most notably for the scale "school", which has a low at the age of 14 years (female $14 \mathrm{y}: \mathrm{m}=54.1 / \mathrm{sd}=20.1$; male $14 \mathrm{y}: \mathrm{m}=54.9 / \mathrm{sd}=20.2$ ). These age-related findings were equally true for males and females. There were no differences between the genders for the scales "parents" and "school", and interactions between age and gender were not meaningful.

The age-specific hypotheses formulated for the social dimension of HRQOL concerning parents and school are confirmed in our study (Tab. 3). In agreement with the gender-specific hypothesis for the scale "school", no gender differences were found across the whole sample. Thus it is true for both genders that HRQOL aspects concerning parents and school decrease noticeably between the ages of nine and 14 years and increase slightly again after that.

\section{Social aspects of HRQOL concerning peers}

For the scale "peers" no age or gender differences were found, and there were no meaningful gender differences for the scale "acceptance" (Fig. 1g). The scale "acceptance" shows an extraordinary age distribution as a single HRQOL scale, however, with higher values throughout increasing age ("acceptance": female $9 \mathrm{y}: \mathrm{m}=72.7 / \mathrm{sd}=20.6$; female $17 \mathrm{y}$ : $\mathrm{m}=87.7 / \mathrm{sd}=13.1 ;$ male $9 \mathrm{y}: \mathrm{m}=72.5 / \mathrm{sd}=22.4$; male 17 $\mathrm{y}: \mathrm{m}=86.8 / \mathrm{sd}=14.8)$. These differences are meaningful. In detail, two noticeable pair differences are found for girls between nine and 12 years and one for boys between 11 and 12 years.

Of the four formulated hypotheses concerning the scales "peers" and "acceptance", we could only confirm the one assuming that quality of life would increase with increasing age in terms of social acceptance (Tab. 3).
Aspects of HRQOL concerning autonomy and financial resources

For the scales "autonomy" and "financial" no hypotheses were formulated and likewise neither of these scales shows statistically significant gender or age differences (Tab. 3).

Across all scales of HRQOL we can assert that no gender differences exist for children. Around the age of 12 years a real break can be noticed: In the physical and psychological dimensions for both genders there is a decrease in quality of life, and this decrease is larger for females than for males. With increasing age, values for adolescents show increasing differences between the genders, with higher values for male adolescents. The values of aspects of HRQOL concerning parents and school decrease for both genders, whereas the values expressing social acceptance increase for both.

\section{Discussion}

In this paper we show differences in health-related quality of life for children and adolescents from seven European countries, broken down by gender and age. The strength of the presented study is mainly that the different aspects of HRQOL could be analysed separately by a new multi-dimensional instrument. Furthermore a sufficient sample size allowed to examine the defined subgroups in detail. However the number of participants was not big enough to distinguish for different countries as well. Thus the question of whether age and gender differences in HRQOL vary depending on culture cannot be answered here. As a further limitation we have to consider the convenience sample mostly recruited in schools which resulted in unbalanced answer rates.

Considering age trends apart from gender and looking at the results from a developmental psychology perspective, many aspects of the decrease in HRQOL during adolescence can be explained. A physical as well as a social transition from childhood to adulthood occurs, often combined with transitions in school or with the beginning of a vocational school. As a result of hormonal development, physiological processes can become so imbalanced that subjective well-being can be impaired (Flammer \& Alsaker 2002). Adolescents experience an increasing discrepancy between their physical and intellectual development on the one hand and their restricted possibilities compared to adults on the other, especially if they remain for a long time in the educational system (Moffitt 1993). They develop their own values and cultural norms, have to adapt to their changing bodies and new gender identities, may desire or consider a role as a partner in romantic love, and in searching for their own identities begin to require more distance from adults (Haberlandt et al. 1995; Schütze 1992). In addition, in the process of individuation adolescents 
are confronted with social and cultural insecurity, moral and value-based contradictions, and uncertainty about the future. Adolescents' unsettled phase can lead to a higher health-related burden (Haberlandt et al. 1995). Increasingly challenging developmental tasks must be handled, and adolescents at this age have an enormous number of new experiences. This, in turn, can help to explain the improvement in quality of life in the area of social acceptance: peers become increasingly more important than adults; as autonomy increases adolescents more frequently choose with whom they want to have contact, and their social skills improve.

Different explanations can be considered for the increase in gender differences in the physical and psychological aspects of HRQOL from the age of 13 years on. One assumption is that puberty is physically more drastic for girls than for boys. Indeed, for girls the onset of menstruation is a cause of many complaints. For 12- to 16-year-old female adolescents, menstruation disorders are the most common health problems following colds and influenza (Kolip et al. 1995b). The major hormonal fluctuations that occur in teenage females additionally can contribute to worse psychological well-being and particularly to greater excitability (Ravens-Sieberer et al. 2003). The stronger impairment observed for girls in comparison to boys in our data corresponds approximately with the beginning of puberty, thus this explanation makes sense. It should also be added that girls and boys handle problems and difficulties in different ways; namely, girls tend to direct their coping patterns inwards, and boys outwards. Thus the more frequent psychosomatic and mental disorders seen in girls in the second decade of life can be further explained (Kolip et al. 1995a). Research shows, moreover, that young women are more worried about their bodies than young men (Flammer \& Alsaker 2002); they are more concerned with themselves and their well-being, and are more sensitive (Langness et al. 2003).

Another attempt to explain gender differences involves the argument that the social demands placed on girls are more contradictory and more difficult to achieve. The uncertainty that affects adolescents (Haberlandt et al. 1995) could be more strongly felt by girls because they are confronted with even more manifold role expectations. Thus today's educators often try to support girls and young women in the development of a strong and autonomous personality, but findings show time and again that boys often have more privileges and are given more space than girls (Chawla 2002). Traditional female stereotypes haven't changed much, either. This is especially true for the beauty ideal confronting girls and young women. Girls begin dieting at ever earlier ages in response to these demands (Haberlandt et al. 1995), and are affected much more often by eating disorders than are boys. This sup- ports the argument that social demands more heavily impair the self-images of young women than those of young men. Relationships with peers change from childhood to adolescence, and girls and young women differ from boys and young men in their social relations (Colarossi \& Eccles 2000; Phillipsen 1999). In the study presented, however, no age- and gender-specific differences were found for the scale "peers". Certainly this is related to the fact that relationships that differ according to age or gender may meet different needs and thus can likewise lead to positive well-being. Apparently the operationalisation of this aspect of HRQOL in the Kidscreen questionnaire is so general that quality of life concerning peers can be measured highly independent of gender and age.

According to the literature, male children and adolescents are more frequent victims of bullying than females, and there are more victims in younger age groups than in older groups (Alsaker 2003; Rigby 2002). Similarly, in our study older respondents reported more positive values in this aspect of HRQOL than younger ones. However, no gender difference was confirmed. Certainly the operationalisation of the social acceptance aspect of HRQOL is defined more broadly than the concrete identification of victims of bullying. Possibly, there are indeed no gender differences in this broader conception, but more investigation is required in this field.

In conclusion, it is clear that meaningful gender and age differences exist in the field of HRQOL of children and adolescents, and that these differences have relevance for the research and practice of public health. We have shown that it is necessary to differentiate among various aspects in order to examine these differences in health-related quality of life. It is also clear that interventions in prevention and health promotion must be age- and gender-specific, and must be designed to reach target groups by emphasising what is important to them.

\section{Acknowledgements}

The KIDSCREEN Project (www.kidscreen.org) is a crossnational effort centring around the development of a crossculturally standardised instrument for the assessment of children's and adolescents health-related quality of life and is funded by the European Commission, contract No.: QLGCT-2000-00751. In Switzerland the project is funded by the Swiss Federal Office for Education and Science.

KIDSCREEN international co-ordinator in chief: Ulrike Ravens-Sieberer, Robert Koch Institute, Berlin, Germany. Members of the KIDSCREEN Group include: Austria: Wolfgang Duer and Kristina Fuerth. Czech Republic: Ladislav Czemy. France: Pascal Auquier, Stephane Robitail, Marie-Claude Simeoni and Delphine Orbicini. Germany: Ulrike Ravens-Sieberer, Angela Gosch, Michael Erhart and 
Ursula von Rueden. Greece: Yannis Tountas and Christina Dimitrakaki. Hungary: Agnes Czimbalmos. Ireland: Jean Kilroe. The Netherlands: Jeanet Bruil, Symone Detmar and Eric Veripps. Poland: Joanna Mazur and Ewa Mierzejewska.
Spain: Luis Rajmil, Silvina Berra and Cristian Tebé. Sweden: Curt Hagquist. Switzerland: Thomas Abel, Corinna Bisegger and Bernhard Cloetta. United Kingdom: Mick Power and Clare Atherton.

\section{Zusammenfassung}

Gesundheitsbezogene Lebensqualität: Geschlechtsunterschiede in Kindheit und Jugend

Fragestellung: Die Studie geht der Frage nach, in welchen Aspekten der gesundheitsbezogenen Lebensqualität (HRQOL) von Kindern und Jugendlichen Geschlechts- und Altersunterschiede zu finden sind und wie weit sie damit theoretischen und empirischen entwicklungspsychologischen Erkenntnissen entsprechen.

Methode: Ein neu entwickelter HRQOL-Fragebogen wurde von 3710 Kindern und Jugendlichen von neun bis 17 Jahren aus sieben europäischen Ländern beantwortet. Der "Kidscreen 52"-Fragebogen besteht aus 10 Skalen, welche Aspekte der physischen, psychischen und sozialen Dimensionen der HRQOL operationalisieren. Der Einfluss von Alter und Geschlecht auf die verschiedenen HRQOL-Aspekte wird mit Hilfe von ANOVA und Effektstärken detailliert berichtet.

Ergebnisse: Kinder bis zum Alter von etwa 12 Jahren berichten weitgehend unabhängig vom Geschlecht über eine sehr gute Lebensqualität. Danach sinkt die Lebensqualität in der Mehrheit ihrer Aspekte. In der körperlichen und psychischen Dimension ist für die weiblichen Jugendlichen eine stärkere Abnahme zu beobachten als für die männlichen Jugendlichen, was bei den älteren Jugendlichen zu einem bedeutend weniger guten Befinden der jungen Frauen führt.

Schlussfolgerung: Die HRQOL von Kindern ist in vielen Aspekten höher als jene der Jugendlichen, mit zunehmendem Alter ist die HRQOL von weiblichen Jugendlichen häufig weniger gut als jene der männlichen Jugendlichen. Eine Betrachtung der einzelnen Aspekte führt zu einer Differenzierung der Ergebnisse mit konkreter Relevanz für Public Health.

\section{Résumé}

Qualité de vie en lien avec la santé: différences entre les sexes chez les enfants et les adolescents

Objectifs: Analyser l'effet du genre et de l'âge sur différents aspects de la qualité de vie en lien avec la santé (HRQOL). Voir dans quelle mesure ces résultats correspondent à des connaissances théoriques et empiriques issues de la psychologie développementale.

Méthodes: 3710 enfants et adolescents de neuf à 17 ans de sept pays européens ont répondu à un questionnaire indiquant la HRQOL. Cet instrument, "Kidscreen 52», se compose de 10 échelles qui mesurent des aspects des dimensions physiques, psychiques et sociales de la HRQOL. L'influence de l'âge et du sexe sur les différents aspects de HRQOL est analysée à I'aide de ANOVA.

Résultats: Les enfants rapportent une qualité de vie très bonne jusqu'à l'âge de 12 ans environ, indépendamment du sexe. Ensuite la qualité de vie baisse. En ce qui concerne les aspects physiques et psychiques, une diminution plus forte est observée chez les jeunes femmes que chez les jeunes hommes. La qualité de vie est ensuite nettement moins bonne chez les jeunes femmes plus âgées.

Conclusion: La HRQOL des enfants est globalement meilleure que celle des adolescents. Avec l'âge, la HRQOL est fréquemment moins bonne pour les jeunes femmes que pour les jeunes hommes. Il faut tenir compte de ces différents aspects pour des actions de santé publique.

\section{References}

Alsaker FD (2003). Quälgeister und ihre Opfer: Mobbing unter Kindern - und wie man damit umgeht. Bern: Huber.
Bergman MM, Scott J (2001). Young adolescents' well-being and health-risk behaviours: gender and socio-economic differences. J Adolesc 24: 183-97.

Bilz L, Hähne C, Melzer W (2003). Die Lebenswelt Schule und ihre Auswirkungen auf die Gesundheit von Jugendlichen. In: Hurrelmann
K, Klocke A, Melzer W, Ravens-Sieberer U, eds. Jugendgesundheitssurvey: internationale Vergleichsstudie im Auftrag der Weltgesundheitsorganisation WHO: Weinheim: Juventa: 243-99.

Bortz J, Döring N (1995). Forschungsmethoden und Evaluation. 2. Aufl. Berlin: Springer. 
Bronfenbrenner U (1981). Die Oekologie der menschlichen Entwicklung. Stuttgart: Klett.

Bullinger M, Morfeld M, Petersen C, RavensSieberer $U$ (2001) Zur gesundheitsbezogenen Lebensqualität von Frauen und Männern. In: Worringen $\mathrm{U}, \mathrm{Zwingmann} \mathrm{Ch}$, eds. Rehabilitation weiblich - männlich: geschlechtsspezifische Rehabilitationsforschung. Juventa: Weinheim: 195-220.

Bullinger M, Siegrist J, Ravens-Sieberer U, eds. (2000). Lebensqualitätsforschung aus medizinpsychologischer und -soziologischer Perspektive. Göttingen: Hogrefe. (Jahrbuch der Medizinischen Psychologie; 18).

Chawla L (2002). The effects of political and economic transformations on children: the environment. In: Kaufman NH, Rizzini I, eds. Globalization and children: exploring potentials for enhancing opportunities in the lives of children and youth. New York: Kluwer Academic: 91-7.

Chipuer HM, Bramston P, Pretty G (2003). Determinants of subjective quality of life among rural adolescents: a developmental perspective. Soc Ind Res 61: 79-95.

Colarossi LG, Eccles JS (2000). A prospective study of adolescents' peer support: gender differences in the influence of parental relationships. J Youth Adolesc 29: 661-78.

Craig WM (1998). The relationship among bullying, victimization, depression, anxiety, and aggression in elementary school children. Pers Individ Diff 24: 123-30.

Detmar SB, Bruil J, Ravens-Sieberer U, Gosch A, Bisegger $C$, and the European Kidscreen group (2005). A focus group approach in constructing the Kidscreen HRQL questionnaire for children and adolescents. (In preparation).

Dreher E, Dreher M (1985). Wahrnehmung und Bewältigung von Entwicklungsaufgaben im Jugendalter. In: Oerter R, ed. Lebensbewältigung im Jugendalter. Weinheim: Edition Psychologie: 56-70.

European Commission (2000). Report on the state of young people's health in the European Union: a Commission Services Working Paper. http://europa.eu.int/comm/health/ph_information/ reporting/ke01_en.pdf.

European Kidscreen group (2005). Manual of the Kidscreen questionnaires: screening for and promotion of health related quality of life in children and adolescents - a European public health perspective. (In preparation).

Fend H (2001). Entwicklungspsychologie des Jugendalters. 2. Aufl. Opladen: Leske und Budrich.
Flammer A, Alsaker F (2002). Entwicklungspsychologie der Adoleszenz: die Erschliessung innerer und äusserer Welten im Jugendalter. Bern: Huber.

Haberlandt M, Höfer R, Keupp H, Seitz R, Straus $F$ (1995). Risiken und Chancen der Entwicklung im Jugendalter. In: Kolip P, Hurrelmann K, Schnabel P-E, eds. Jugend und Gesundheit: Interventionsfelder und Präventionsbereiche. Weinheim: Juventa: 87-109.

Haugland S, Wold B, Stevenson J, Aaroe LE, Woynarowska B (2001). Subjective health complaints in adolescence: a cross-national comparison of prevalence and dimensionality. Eur $\mathbf{J}$ Public Health 11: 4-10.

Havighurst RJ (1966). Developmental tasks and education. New York: McKay.

Herdman M, Rajmil L, Ravens-Sieberer U, Bullinger $M$, Power $M$, Alonso J, and the European Kidscreen and Disabkids group (2002). Expert consensus in the development of a European health-related quality of life measure for children and adolescents: a Delphi study. Acta Paediatr 91: 1385-90.

Klocke A, Becker U (2003). Die Lebenswelt Familie und ihre Auswirkungen auf die Gesundheit von Jugendlichen. In: Hurrelmann K, Klocke A, Melzer W, Ravens-Sieberer U, eds. Jugendgesundheitssurvey: internationale Vergleichsstudie im Auftrag der Weltgesundheitsorganisation WHO. Weinheim: Juventa: 183-241.

Kolip P, Hurrelmann K, Schnabel P-E (1995a). Gesundheitliche Lage und Präventionsfelder im Kindes- und Jugendalter. In: Kolip P, Hurrelmann K, Schnabel P-E, eds. Jugend und Gesundheit: Interventionsfelder und Präventionsbereiche. Weinheim: Juventa: 7-21.

Kolip P, Nordlohne E, Hurrelmann K (1995b). Der Jugendgesundheitssurvey 1993. In: Kolip P, Hurrelmann K, Schnabel P-E, eds. Jugend und Gesundheit: Interventionsfelder und Präventionsbereiche. Weinheim: Juventa: 25-48.

Kolip P, Schmidt B (1999). Gender and health in adolescence. Copenhagen: WHO. (Health policy for children and adolescents; 2). http: //www.euro.who.int/document/e66082.pdf.

Langness A, Richter M, Hurrelmann K (2003). Zusammenfassung der Ergebnisse und Konsequenzen für eine jugendgerechte Prävention und Gesundheitsförderung. In: Hurrelmann K, Klocke A, Melzer W, Ravens-Sieberer U, eds. Jugendgesundheitssurvey: internationale Vergleichsstudie im Auftrag der Weltgesundheitsorganisation WHO. Weinheim: Juventa: 301-6.

Moffitt TE (1993). Adolescence-limited and lifecourse-persistent antisocial behavior: a developmental taxonomy. Psychol Rev 100: 674-701.
Narring F, Tschumper A, Inderwildi Bonivento L, et al. (2004). Gesundheit und Lebensstil 16- bis 20-jähriger in der Schweiz (2002): SMASH 2002: Swiss multicenter adolescent survey on health 2002. Lausanne: Institut Universitaire de Médecine Sociale et Préventive.

Nutbeam $D$ (2000). Health literacy as a public health goal: a challenge for contemporary health education and communication strategies into the 21st century. Health Promot Int 15: 259-67.

Phillipsen LC (1999). Associations between age, gender and group acceptance and three components of friendship quality. J Early Adolesc 19: 438-64.

Rajmil L, Herdman M, Fernández de Sanmamed $M J$, et al. and the Kidscreen group (2004). Generic health-related quality of life instruments in children and adolescents: a qualitative analysis of content. J Adolesc Health 34: 37-45.

Ravens-Sieberer U, Gosch A, Abel T, et al. and the European Kidscreen Group (2001). Quality of life in children and adolescents: a European public health perspective. Soz Praventiv Med 46: 297-302.

Ravens-Sieberer U, Görtler E, Bullinger M (2000). Subjektive Gesundheit und Gesundheitsverhalten von Kindern und Jugendlichen - eine Befragung Hamburger Schüler im Rahmen der schulärztlichen Untersuchung. Gesundheitswesen 62: 148-55.

Ravens-Sieberer U, Thomas Ch, Erhart $M$ (2003). Körperliche, psychische und soziale Gesundheit von Jugendlichen. In: Hurrelmann K, Klocke A, Melzer W, Ravens-Sieberer U, eds. Jugendgesundheitssurvey: internationale Vergleichsstudie im Auftrag der Weltgesundheitsorganisation WHO. Weinheim: Juventa: 19-98.

Rigby K (2002). Bullying in childhood. In: Smith $\mathrm{PK}$, Hart CH, eds. Blackwell handbook of childhood social development. Oxford: Blackwell: 549-68.

Roeser RW, van der Wolf K, Stobel KR (2001). On the relation between social-emotional and school functioning during early adolescence: preliminary findings from Dutch and American samples. J School Psychol 39: 111-39.

Schäfer M (1996). Aggression unter Schülern: eine Bestandesaufnahme über das Schickanieren in der Schule am Beispiel der 6. und 8. Klassenstufe. Report Psychologie 21: 700-11.

Schütze $Y$ (1992). Jugend und Familie. In: Krüger HH. Handbuch der Jugendforschung. 2. erw. und aktualisierte Aufl. Opladen: Leske und Budrich: 335-50. 
Health-related quality of life:

gender differences in childhood and adolescence

Simeoni MC, Auquier P, Antoniotti S, Sapin C, San Marco JL (2000). Validation of a French health-related quality of life instrument for adolescents: the VSP-A. Qual Life Res 9: 393-403.

Topolski TD, Patrick DL, Edwards TC, Huebner CE, Connell FA, Mount KK (2001). Quality of life and health-risk behaviors among adolescents. J Adolesc Health 29: 426-35.
Wade TJ, Vingilis E (1999). The development of self-rated health during adolescence: an exploration of inter- and intra-cohort effects. Can J Public Health 90: 90-4.

Wolman C, Resnick MD, Harris LJ, Blum RW (1994). Emotional well-being among adolescents with and without chronic conditions. J Adolesc Health 15: 199-204.

\section{Address for correspondence}

Corinna Bisegger, lic. phil. I Institut für Sozial- und Präventivmedizin Universität Bern

Niesenweg 6

CH-3012 Bern

e-mail: bisegger@ispm.unibe.ch

\section{(1) To access this journal online: (20) http://www.birkhauser.ch}

